\title{
Diatom fluxes in surface sediments of the Goban Spur continental margin, NE Atlantic Ocean
}

\author{
ROBERTO BAO, ${ }^{1}$ HENKO DE STIGTER ${ }^{2} \&$ TJEERD C. E. VAN WEERING ${ }^{2}$ \\ ${ }^{1}$ Universidade da Corua, Facultade de Ciencias, Campus da Zapateira s/n, 15071 A Coruña, Spain (e-mail: xerobert@udc.es). \\ ${ }^{2}$ Netherlands Institute for Sea Research (NIOZ), P.O Box 59, 1790 AB Den Burg, Texel, The Netherlands (e-mail: haas@nioz.nl and \\ tjeerd@,nioz.nl).
}

\begin{abstract}
Continental slopes are presumed key areas for deposition of organic carbon exported from the shelf. Analysis of across-slope differences in diatom and silicoflagellate fluxes recorded in bottom sediments of the Goban Spur margin, a typical North Atlantic slope environment, was carried out to test if they can provide information on the magnitude of advection of material from the shelf into deeper waters. Total diatom and silicoflagellate accumulation rates showed strong across-slope differences. Minimum values are recorded at the shelf break where maximum surface productivity conditions occur while the deeper sampling stations record fluxes as high as $183 \times 10^{6}$ valves $\mathrm{cm}^{-2} \mathrm{ka}^{-1}$. While high diatom fluxes show a clear correspondence with the activity of a permanent bottom nepheloid layer operating in the region, they do not correlate with productivity patterns observed in the water column. Diatom assemblages are mainly composed of Chaetoceros resting spores and Thalassionema nitzschioides (Grunow) Grunow ex Hustedt, typical indicators of spring bloom conditions in the area. The absence of clear across-slope trends in the diatom assemblages is interpreted as the effect of random mixing driven by the strong hydrodynamic regime provoked by the activity of the bottom nepheloid layer. The dominance of Chaetoceros resting spores across the slope is related to important exportation of shelf-derived production. However, due to the broad ecological tolerances of the main taxa composing the diatom assemblages, they do not allow precise estimations on the magnitude of the primary vertical fux vs. the secondary lateral flux in this slope environment. Use of the tychoplanktonic and benthic diatoms, which are restricted to the neritic realm, allows only the estimation of the minimum amount of shelf-derived diatoms reaching the slope sediments (at least 13\% of the total diatom assemblage for the upper slope area of the Goban Spur). This study shows that major limitations exist for the use of diatoms preserved in surface sediments of this area as tracers of shelf-derived production transported to the continental slope. I. Micropalaeontol. 19(2): 123131, December 2000.
\end{abstract}

\section{INTRODUCTION}

The world's continental margins constitute key areas for understanding the global carbon biogeochemical cycling (Walsh, 1991). It has been reported that over $90 \%$ of the organic carbon preserved in marine sediments is stored in the continental margin areas (Berner, 1982). The possibility that continental slopes may act as depocentres for organic material produced on the shelf (Walsh et al., 1981) makes it relevant to determine the magnitude of fluxes of particulate matter across the margins.

Values of organic carbon in slope sediments are usually higher than those at similar depths in the open ocean. On continental slopes, particulate matter inputs to the seafloor are usually derived from both a primary pelagic vertical flux and a secondary lateral flux of shelf-derived production transported within intermediate and bottom nepheloid layers (Gardner, 1989). Thus material balance on the slope cannot be established by considering vertical sedimentation alone, and lateral supply of organic matter has to be taken into account (Graf, 1992). For this reason distinction between the two sources of material inputs to the sediments is of primary importance.

Trends in microfossil fluxes recorded in the bottom sediments across continental slopes could potentially provide information on the magnitude and distribution of material exported from the shelf to the continental slope and ocean basins. In the Norwegian Sea downslope transport is indicated by the occurrence of neritic dinoflagellate cysts (Samtleben et al., 1995) and high fluxes of coccoliths coming from the Barents shelf recorded in traps (Samtleben \& Bickert, 1990). In the Celtic Sea continental slope, the presence of characteristic mid-slope benthic foraminifera at lower depths has also given evidence of lateral supply (Weston, 1985).

Diatom skeletal remains preserved in surface sediments of the northeastern Atlantic have proven to be useful indicators of temperature, upwelling, oceanic productivity, terrigenous influence or water masses (Maynard, 1976; Barde, 1981; Abrantes, 1988; Koç Karpuz \& Schrader, 1990; Bao et al., 1997), although sometimes the preserved diatom signal in the sediments has no clear correspondence with oceanographic features of the water column (Schrader et al., 1993). In this context, complex hydrodynamics of slope environments (Huthnance, 1995) could make diatom assemblages preserved in them strongly biased for interpretations of processes operating in the overlying water column. The low biogenic silica content of north Atlantic Ocean sediments and resulting dissolution (Ruddiman \& McIntyre, 1976) might also obscure the oceanographic significance of the preserved diatom thanatocoenoses. Alternatively, instead of reflecting features of the overlying water mass, diatoms could be used as indicators of near-seabed processes, such as downslope bottom transport and resuspension phenomena. Diatom assemblages in slope environments could therefore be considered as potential tracers of both local oceanographic characteristics and/or of the magnitude of particle bottom transport from the shelf.

The Goban Spur lies on the continental slope off SW England and Ireland (Fig. 1). It is part of a continental margin characterized by a broad, gently sloping shelf extending from the Celtic Sea. Its stepped morphology is the result of the early rifting history of this margin (Masson et al., 1985). A 


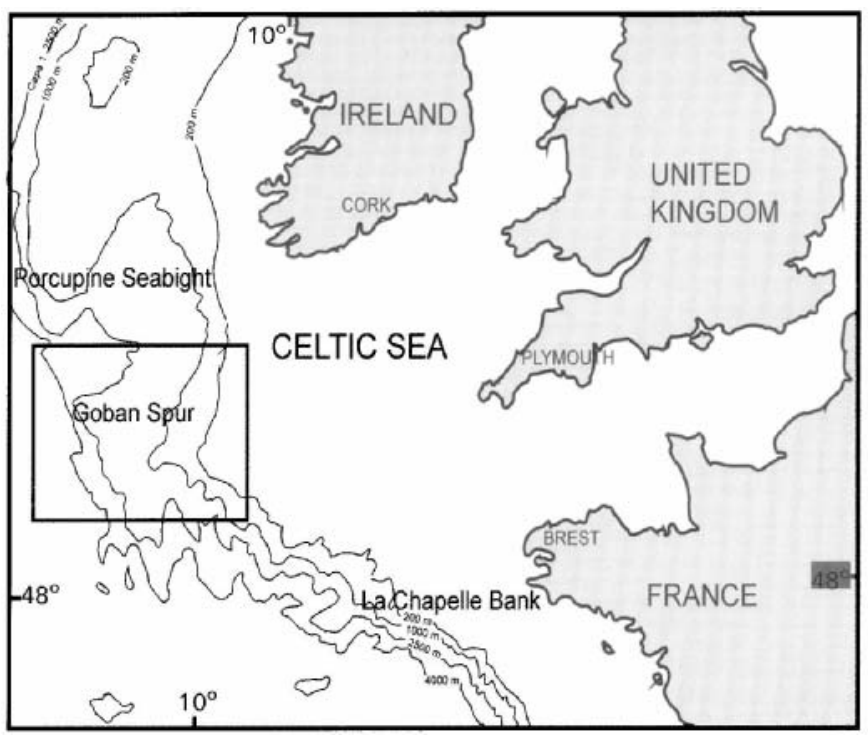

Fig. 1. Location of the area studied.

multidisciplinary study was conducted at the shelf edge and slope of Goban Spur during the European Union-funded Ocean Margin EXchange (OMEX I) programme in order to evaluate the transport of material from the shelf to the deep sea. Results of the first phase of this programme showed that there is evidence of important advection phenomena taking place at this margin (van Weering et al., 1998; Antia et al., 1999; McCave et al., 2000).

The aim of this work is to describe the diatom thanatocoenoses preserved in surface sediments across the Goban Spur margin, to study their significance as indicators of the oceanographic features of the water column and as potential estimators of the magnitude of diatoms being exported from the shelf waters to the open sea. This could contribute to a better understanding of the importance of organic carbon shelf export to the continental slopes.

\section{MATERIALS AND METHODS}

Surface sediment samples were collected with a box corer along two transects perpendicular to the Goban Spur continental slope, during two cruises with $R / V$ Pelagia in October 1993 and $R / V$ Charles Darwin in May/June 1994 (Fig. 2a,b). The 0-1 cm surface sediment of 12 box cores was taken for diatom analysis. All the samples were treated following standard acid cleaning (Schrader, 1973) with some minor modifications. An aliquot of each cleaned sample was mounted on $22 \times 22 \mathrm{~mm}$ coverglasses with Hyrax (refractive index $=1.7$ ). Counts were made at $1000 \times$ with a Nikon Optiphot II phase contrast microscope, with the exception of the sample from station D86-11 which contained no diatoms (Table 1). At least 300 valves were counted per sample following standard counting procedures (Schrader \& Gersonde, 1978). Silicoflagellate specimens were also counted.

Relative percent abundances of the most important taxa were calculated for each sample. Species were grouped according to their ecological characteristics (e.g. Hustedt, 1927-1966; Hendey, 1964; Hasle, 1976; Sancetta, 1982; Ricard, 1987; Denys,

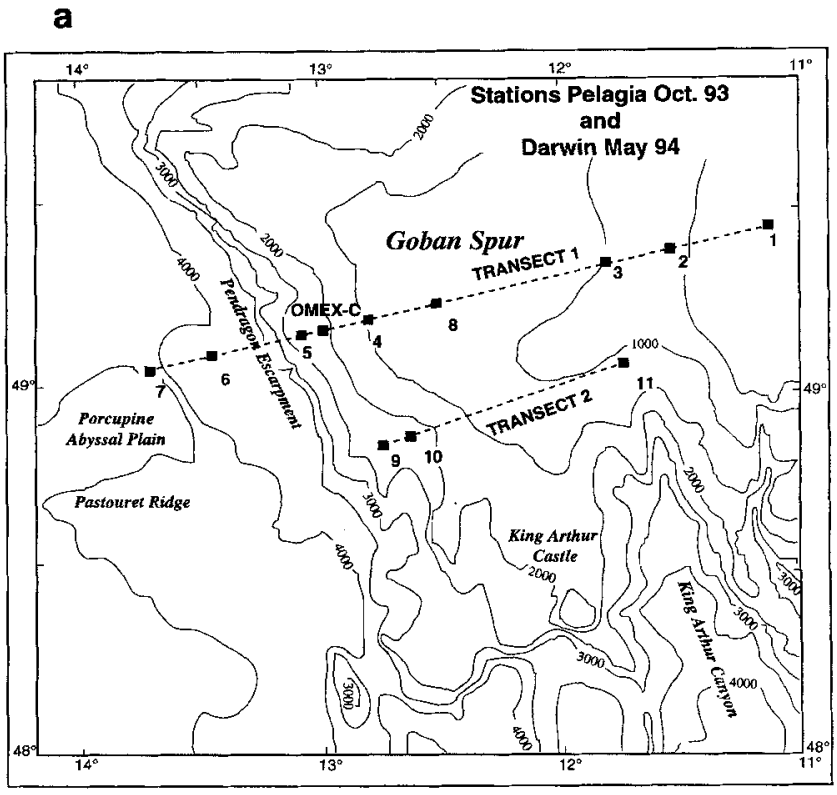

b

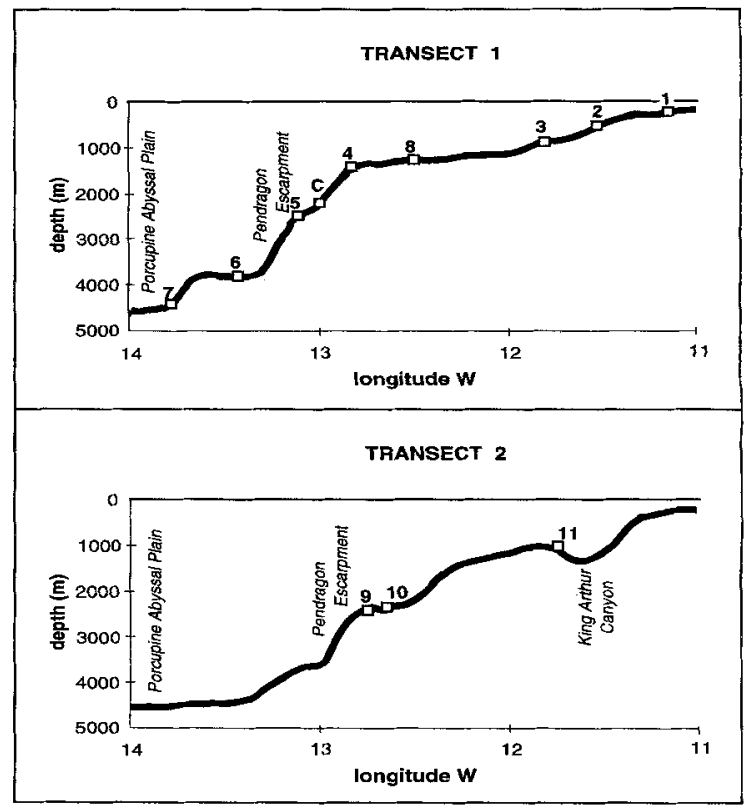

Fig. 2. (a) Transects and boxcore sampling stations across the Goban Spur margin; (b) bathymetric sections.

$1991 \mathrm{a}, \mathrm{b}$; Hasle \& Syvertsen, 1996) (Table 2). Absolute diatom and silicoflagellate abundance estimates (valves $\mathrm{g}^{-1}$ dry sediment) were made using Lycopodium spores following the procedure described in Kaland \& Stabell (1981). Diatom accumulation rates (DAR; valves $\mathrm{cm}^{-2} \mathrm{ka}^{-1}$ ) and silicoflagellate accumulation rates (SAR; skeletons $\mathrm{cm}^{-2} \mathrm{ka}^{-1)}$ were calculated using the obtained absolute diatom and silicoflagellate abundances, the dry bulk density of the sediment, and the sedimentation rates estimated on the basis of ${ }^{14} \mathrm{C}$ calibrated 
Diatoms of the Goban Spur continental margin

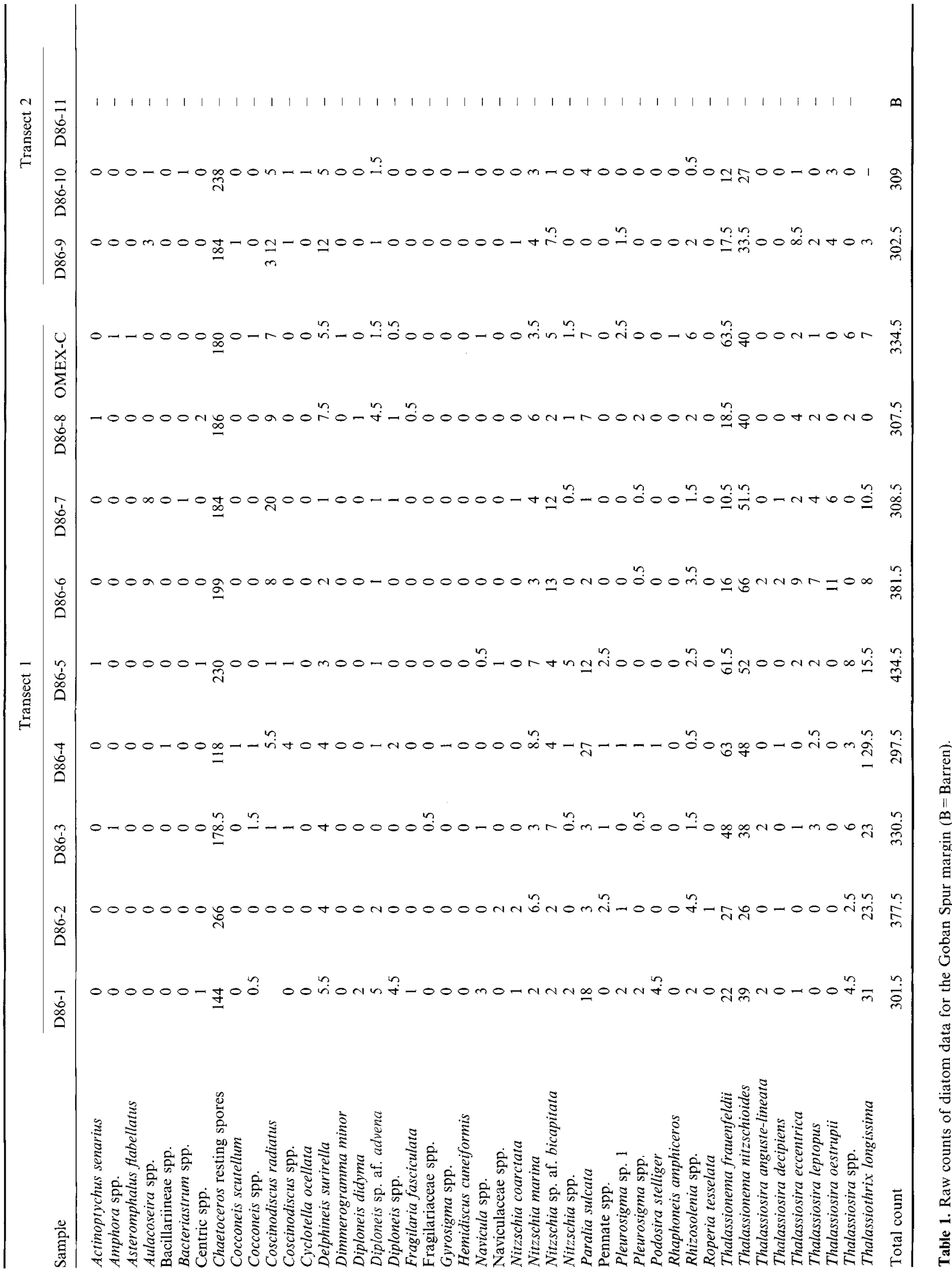


Taxa grouped as pelagic

Taxa grouped as neritic

Holoplanktonic or meroplanktonic condition

Asteromphalus flabellatus

Chatoceros resting spores

Thalassionema nitzschioides

Thalassiosira decipiens

Thalassiosira eccentrica
Tychoplanktonic or benthic condition
Coscinodiscus radiatus

Hemidiscus cuneiformis

Nitzschia marina

Roperia tesselata

Thalassionema frauenfeldii

Thalassiosira anguste-lineata

Thalassiosira leptopus

Thalassiosira oestrupii

Thalassiothrix longissima

\author{
Actinoptychus senarius \\ Amphora spp. \\ Cocconeis scutellum \\ Cocconeis spp. \\ Delphineis surirella \\ Dimmerogramma minor \\ Diploneis didyma \\ Diploneis sp. af. advena \\ Diploneis spp. \\ Fragilaria fasciculata \\ Navicula spp. \\ Nitzschia coarctata \\ Paralia sulcata \\ Podosira stelliger \\ Rhaphoneis amphiceros
}

Source for the groups is a literature survey of the ecological requirements attributed to the taxa (most summarized in Denys, $1991 \mathrm{a}, \mathrm{b}$ ).

Table 2. Ecological grouping of diatom taxa.

planktonic foraminiferal or lithostratigraphic datum levels (van Weering et al., 1998).

\section{RESULTS}

Diatom accumulation rates on the Goban Spur margin range from $2.2 \times 10^{6}$ to $183 \times 10^{6}$ valves $\mathrm{cm}^{-2} \mathrm{ka}^{-1}$ for transect 1 and from 0 to $86 \times 10^{6}$ valves $\mathrm{cm}^{-2} \mathrm{ka}^{-1}$ for transect 2 (Fig. 3). Sediments from station D86-11 were barren of diatoms. Diatom fluxes in the surface sediments are, in general terms, low for the upper slope stations, increasing downslope, with the exception of station D86-5 at Pendragon Escarpment. Silicoflagellate accumulation rates show a similar pattern, with the exception of station D86-5, which records a higher flux than the more onshore OMEX-C station. Sediment accumulation rates are highest on the shelf, decreasing with increasing water depth till about $1500 \mathrm{~m}$, and increasing again deeper downslope. The largest discrepancy between total sediment flux and siliceous microfossil accumulation rates is detected at the most proximal positions in both transects (stations D86-1 and D86-11), where maximum mass accumulation rates and minimum microfossil fluxes are recorded.

In spite of the high diatom accumulation rates found in some parts of the slope, diatom diversity is low, with only 45 taxa identified in both transects. Nearly all taxa found on Goban Spur are robust forms, possibly indicating strong dissolution of the diatom assemblages. This is also noticed in the high numbers of valves showing dissolution at their margins. The most common diatom taxa include Chaetoceros resting spores, which range from 47 to $77 \%$ of the total diatom assemblage, Thalassionema nitzschioides (Grunow) Grunow ex Hustedt, Thalassionema frauenfeldii (Grunow) Hallegraeff, Thalassiothrix longissima Cleve \& Grunow and Paralia sulcata (Ehrenberg) Cleve. All these taxa together make up 79 to $91 \%$ of the total diatom assemblages. Chactoceros resting spores dominate in all stations. Vegetative Chaetoceros cells were not found, nor differences in the state of preservation of the spores.

No clear trends can be seen in the across-slope variations in relative abundance of these taxa (Fig. 4), with the exception of an increase in the abundance of Thalassionema frauenfeldii at the mid-slope stations, followed by a decrease deeper downslope, and the Paralia sulcata peaks at the shelf (station D86-1) and upper slope (station D86-4) positions. Silicoflagellates show a high degree of fragmentation. Only two species, Distephanus speculum (Ehrenberg) Haeckel and Dictyocha fibula Ehrenberg, were recorded.

Diatom taxa were grouped according to their ecological characteristics as pelagic and neritic (Table 2). A distinction in the latter was made between those having a planktonic life-form and those having a tychopelagic or purely benthic character. The reason for this separation is that neritic diatoms having a planktonic condition, although preferentially distributed in shelf/coastal waters, can sometimes be abundant in the open ocean. On the contrary, tychopelagic and benthic diatoms cannot complete their whole life-cycle in the oceanic environment, being restricted to the neritic realm. Tychopelagic diatoms are facultatively planktonic during a short interval of their lifecycle (mainly during resuspension events), most of their life being benthic. The benthic group includes epipsammic, epipelic, as well as epiphytic diatoms which live in the inner shelf attached to a substrate.

Distribution of the different groups along both transects shows the dominance of the neritic planktonic diatoms in all stations due to the overwhelming contribution of the Chaetoceros resting spores to this group (Fig. 5). There is no evident sorting of the different groups along the transects. However, distribution patterns of tychopelagic and benthic diatoms will be treated in more detail since they are strictly allochthonous material transported to the slope from the shelf.

Maximum diatom accumulation rates for the benthic and tychopelagic groups are recorded in the OMEX-C station (Fig. 6). This situation contrasts with that of total DAR (Fig. 3). Cumulative percent abundances of both groups show two peaks in the shelf and upper slope stations (D86-1 and D86-4), representing about $13-15 \%$ of the total assemblage in these 

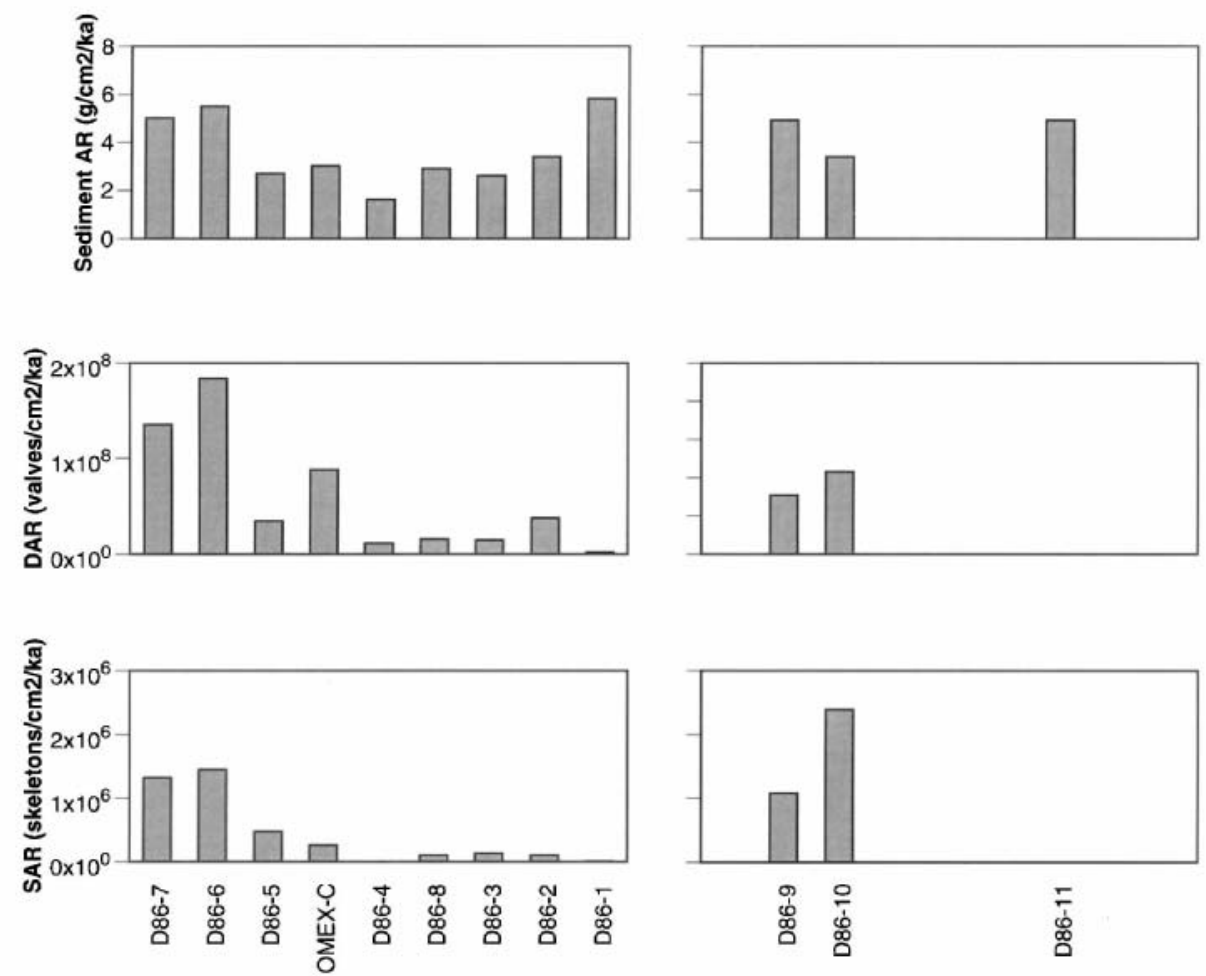

Fig. 3. Late Holocene sediment accumulation rates (from van Weering et al., 1998) in $\mathrm{g} \mathrm{cm}^{-2} \mathrm{ka}^{-1}$, diatom (DAR) and silicoflagellate (SAR) accumulation rates in valves and skeletons $\mathrm{cm}^{-2} \mathrm{ka}^{-1}$, respectively. DAR and SAR are not on the same scale.

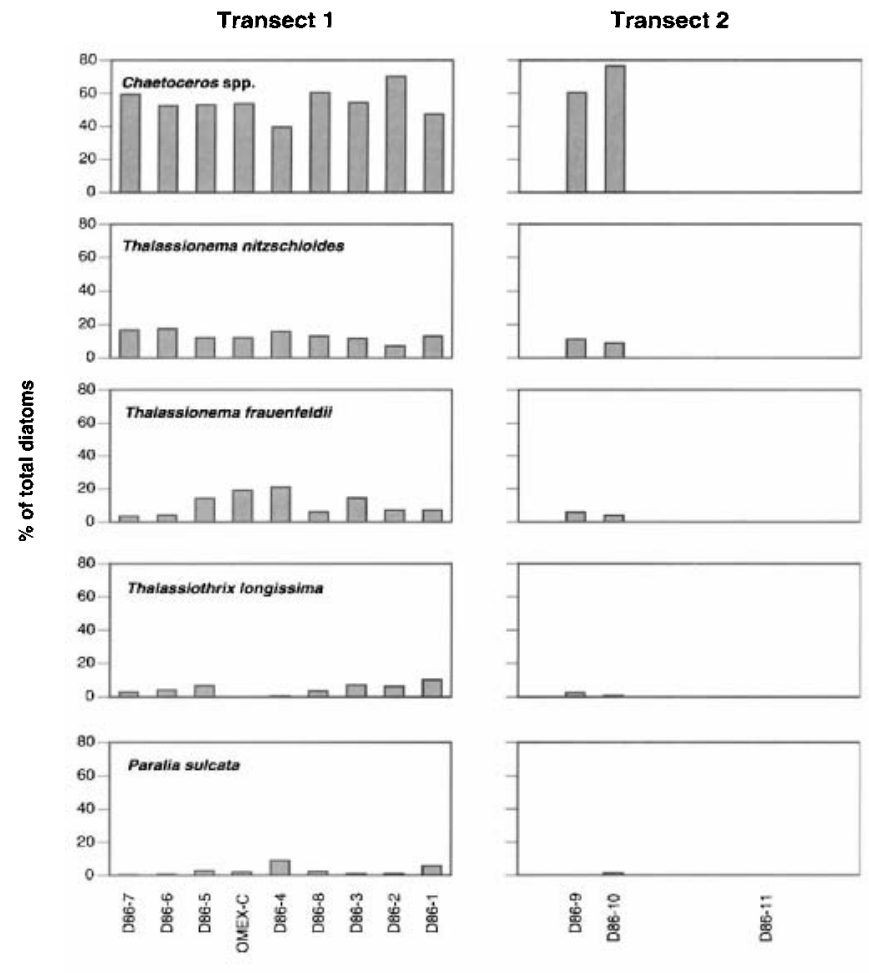

Fig. 4. Relative abundances of the most common diatom taxa. positions. Their relative abundances diminish to the lower slope and represent slightly over $1 \%$ of the total assemblage at station D86-6. This diminution is parallel to that of their accumulation rates.

\section{DISCUSSION}

\section{Total diatom fluxes}

The observed trends in total diatom fluxes in the two transects studied reflect, in general terms, the hydrodynamic and sedimentary regimes present at the Goban Spur. A high energy current regime results in minimum diatom and silicoflagellate accumulation rates (DAR and SAR) on the upper to mid-slope areas, while maximum fluxes are recorded at the deeper stations where high mass accumulation rates take place (van Weering et al., 1998). Notwithstanding high sediment accumulation rates on the shelf edge (station D86-1), very low DAR and SAR are found at this location. Low DAR and SAR cannot be attributed to reduced productivity of the euphotic zone, because highest nutrient and chlorophyll concentrations in the Goban Spur surface waters are present at the shelf break (Pingree $\&$ Mardell, 1981; Garcia-Soto \& Pingree, 1998) due to doming of the thermocline, causing the injection of new nutrients to the euphotic zone (Pingree et al., 1976). Low diatom and silicoflagellate concentrations in the sediments at this site and probably at station D86-11 may therefore be attributed to strong opal dissolution. Intense near-surface water silica dissolution takes place at the Goban Spur margin. Antia et al. 

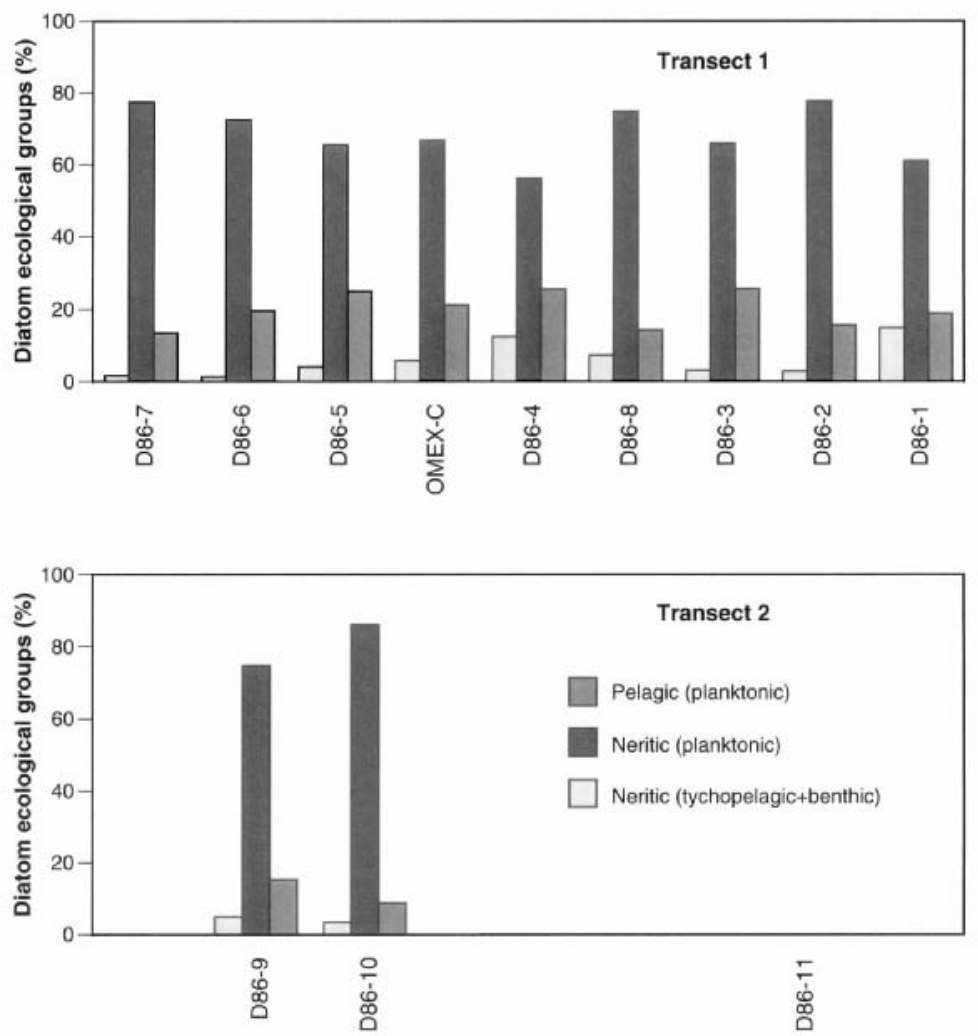

Fig. 5. Relative abundances of the ecological groups defined according to Table 2.

(1999) report a production of $7.5 \mathrm{~g}$ opal m $\mathrm{m}^{-2} \mathrm{a}^{-1}$ sedimenting only $1 \mathrm{~g} \mathrm{~m}^{-2} \mathrm{a}^{-1}$ to $600 \mathrm{~m}$. About $85 \%$ of opal produced in the upper layer undergoes dissolution in the area. A low opal supply rate from the water column to the seabed could therefore explain enhanced dissolution at this site since impact of dissolution at the bottom increases rapidly as opal accumulation rate decreases (Pokras, 1986). On the other hand, diatom enrichment of the downslope stations must be attributed to the effects of downslope near-seabed advective flux of particles. Trap studies have shown that particulate biogenic silicate fluxes reaching deeper waters at the Goban Spur margin are more than four times as high as near-surface fluxes (Antia et al., 1999), indicating that lateral supply causes a considerable input of siliceous particles to the deeper waters. This input is probably even higher than revealed by trap studies since the total arrival flux at the bottom comprises a large proportion of material transported at less than $5 \mathrm{~m}$ above the seabed (McCave et al., 2000). All these data support the idea that total diatom fluxes to the bottom of this continental slope do not have a direct correspondence with productivity conditions of the overlying water column, but are mainly the consequence of intense lateral supply from the shelf waters.

\section{Composition of diatom assemblages}

Differential dissolution and the capability of certain taxa to flourish during more than one season may produce diatom thanatocoenoses not representing the period of maximum flux from the water column (Sancetta, 1989; Crosta et al., 1997).
Species composition of transects accross the Goban Spur is largely dominated by Chaetoceros resting spores and Thalassionema nitzschioides. Both taxa appear in large numbers during spring bloom conditions in the Goban Spur area, being greatly reduced the rest of the year (Rees et al., 1999). Trap studies also indicate that annual peak silicate fluxes occur during spring and are enhanced in the deeper traps by the effect of lateral influx (Antia et al., 1999). Large amounts of siliceous debris can also be exported from the shelf break after the summer, but because of the strong seasonality of phytoplankton production, it is likely that exported material consists mostly of previously sedimented spring diatoms.

Across-slope distribution of the most common taxa and ecologically defined groups does not show consistent variations. This fact might be interpreted as an effect of random mixing of the diatom assemblages (Sancetta \& Calvert, 1988). In our case, this would be driven by strong hydrodynamics on the slope caused by the activity of nepheloid layers. While intermediate nepheloid layers are weakly developed and have a temporary character, the bottom nepheloid layer over the Goban Spur margin is permanent and is probably the dominant sediment transport mechanism on this continental slope (McCave et al., 2000).

High numbers of Chaetoceros resting spores in both transects raises the question about the origin of their enrichment in these sediments. Pelagic nearshore sediments can strongly be enriched in Chaetoceros spores by the effects of advection from the continental shelf (Sancetta, 1992). SEM analysis of filtered 

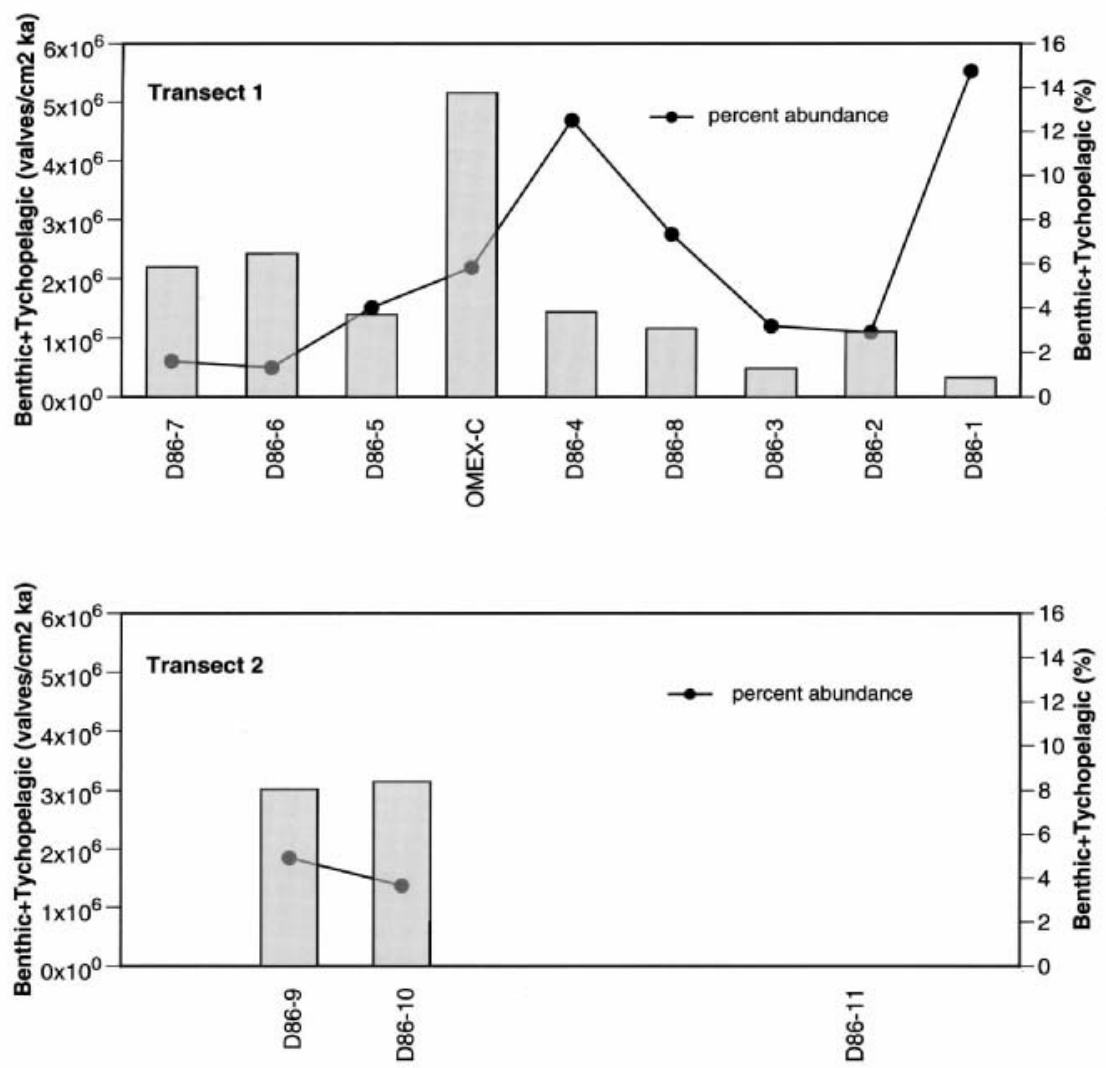

Fig. 6. Diatom accumulation rates and relative abundance of the benthic and tychopelagic groups.

suspended particles of the intermediate and bottom nepheloid layers of the Goban Spur have shown very high amounts of Chaetoceros resting spores (I. N. McCave pers. comm.). In view of the episodic character of intermediate nepheloid layers, transport by the permanent bottom nepheloid layer coming from inshore positions to the slope must be the major pathway for Chactoceros resting spores.

Although most abundant in neritic environments, Chaetoceros is also a common taxon in the open ocean (Rines \& Hargraves, 1988), as is the case of the Goban Spur margin (Rees et al., 1999). Nevertheless, some data point to a minor Chaetoceros vertical flux to the sediments. Delicate Chaetoceros vegetative cells do not appear at the bottom, suggesting dissolution in the water column during settling. This is supported by the maximum silica dissolution in the near-surface waters observed at Goban Spur (Antia et al., 1999). Intense silica dissolution may not only affect delicate diatom forms, but also heavily silicified resting spores which, as a result, may have strongly reduced fluxes (Samtleben et al., 1995). However, the lack of differences in the state of preservation of the spores along both transects does not help to definitely distinguish between autochthonous Chaetoceros spores that could be settled from the overlying photic zone and those transported within the bottom nepheloid layer. Although most of the spores can, on the basis of known Chaetoceros autoecology (Rines \& Hargraves, 1988), be assumed to have originated from the shelf area, some unknown enrichment by vertical settling cannot be totally excluded.
Therefore, it is not possible in our case to quantify the contribution of spores coming from the shelf to the oceanic areas only by the study of diatom thanatocoenoses. This clearly illustrates the difficulty of interpreting the significance of Chaetoceros-rich sediments in most situations (Sancetta, 1992).

Benthic and tychopelagic diatoms could be better tracers for knowing the magnitude of the contribution of the shelf material to the total diatom assemblage. Both groups constitute, due to their habitat requirements, unequivocal indicators of shelfderived production, since they cannot grow in slope environments. Their relative abundances indicate that at least $13-15 \%$ of the total diatom assemblage in the sediments of the upper slope and outer shelf are composed of allochthonous diatoms coming from inner shelf positions. These figures, however, must be taken only as minimum estimates (Falkowski et al., 1994). A high relative abundance for the two combined groups at station D86-4 could explain their relatively high accumulation rate recorded at the adjacent station OMEX-C. Intense resuspension takes place at the Goban Spur slope between $1000-1460 \mathrm{~m}$ (Thomsen \& van Weering, 1998; van Weering et al., 1998), accounting for a large proportion of the total fluxes in the sediment traps deployed in the area (Antia et al., 1999). The resuspension of these sediments enriched in benthic and tychopelagic diatoms (station D86-4) could contribute to the maximum valve fluxes for these groups recorded at station OMEX-C.

The strong reduction in relative abundance of the tychope- 
lagic and benthic components at the deepest stations, and its uncoupling from the total diatom accumulation rate (Fig. 3) may be interpreted as an indication of an absolute decrease in the contribution of displaced shallow-water diatoms to the total flux at deeper stations, and enhanced vertical settling. This is in agreement with data on sediment grain size distribution, which show an increase in the finer fractions to the deeper stations (van Weering et al., 1998) and with SEM studies of filtered particles of the bottom nepheloid layer, which also indicate an increase in the vertical particle flux at these positions (McCave et al., 2000).

\section{CONCLUSIONS}

(1) Diatom and silicoflagellate accumulation rates do not directly reflect productivity of the overlying water column across the Goban Spur continental slope. Lowest accumulation rates are recorded in the most productive shelf edge as a consequence of strong opal dissolution taking place at the seabed. Maximum diatom and silicoflagellate fluxes are recorded in the deeper slope due to advective flux of particles mediated by the activity of a permanent bottom nepheloid layer.

(2) No clear across-slope trends can be found in the composition of the sediment diatom assemblages probably due to the strong hydrodynamic regime causing a more or less intense random mixing of diatoms.

(3) Diatom fluxes recorded in the sediments of the Goban Spur slope do not allow a precise quantification of the relative importance of the primary vertical diatom flux and the secondary advective flux to the seafloor. This quantification is strongly biased by the dominance of the Chaetoceros resting spores in the sediment diatom assemblages. Although most of the Chactoceros spores in the sediments are supposed to be transported downslope from the shelf, broad habitat preferences of this taxon cannot rule out some enrichment by vertical settling. Benthic and tychopelagic diatoms give only minimum estimates of diatoms transported by advective processes. At least $13 \%$ of diatom fluxes to the upper slope consist of diatoms originating from the shelf. A combined study relating fossil diatom distributions in the bottom sediments with seasonal diatom flux variations recorded in trap studies and diatom composition of the nepheloid layers is necessary to test out the indicator value of diatoms for estimating the importance of lateral transport in slope environments affected by strong opal dissolution.

(4) Diatom-based palaeoproductivity estimates in slope environments need to be corrected for the effects of allochthonous supply of diatoms coming from the shelf. For the specific case of the Goban Spur, surface sediment samples of this slope environment must be excluded from data sets for the construction of any diatom-based transfer function.

(5) Differences in the local topographic features, biological response patterns and hydrographic regimes create a large variety of shelf-slope systems along the European continental margin. Although these varying settings may provide important differences in the patterns of diatom accumulation in slope sediments, results presented in this paper indicate that strong hydrodynamic conditions and a poor knowledge of the autoecologies of many diatom taxa and of their taphonomy can make of limited value the diatom-based (palaeo)oceanographic inferences in the slope environments of the world.

\section{ACKNOWLEDGEMENTS}

This work was supported by the European Union in the framework of the MAST programme, contract no. MAS2CT93-0069 (Ocean Margin EXchange - OMEX). We specially thank Malcolm Hart and two anonymous reviewers for helpful comments which improved the original manuscript.

\section{Manuscript received October 1998 Manuscript accepted September 2000}

\section{REFERENCES}

Abrantes, F. 1988. Diatom assemblages as upwelling indicators in surface sediments off Portugal. Marine Geology, 85: 15-39.

Antia, A. N., von Bodungen, B. \& Peinert, R. 1999. Particle flux across the mid-European Continental Margin. Deep-Sea Research, 46: 1999 2024.

Bao, R., Varela, M. \& Prego, R. 1997. Mesoscale distribution patterns of diatoms in surface sediments as tracers of coastal upwelling of the Galician shelf (NW Iberian Peninsula). Marine Geology, 144: 117-130.

Barde, M. F. 1981. Les diatomées des sédiments actuels et du Quaternaire supérieur de l'Atlantique Nord-Oriental. Intérêt hydrologique et climatique. Bulletin Institut de Géologie du Bassin d'Aquitaine, Bordeaux, 29: 85-111.

Berner, R. A. 1982. Burial of organic carbon and pyrite sulphur in the modern ocean: its geological and environmental significance. American Journal of Science, 282, 451-473.

Crosta, X., Pichon, J. J. \& Labracherie, M. 1997. Distribution of Chactoceros resting spores in modern peri-Antarctic sediments. Marine Micropaleontology, 29: 283-299.

Denys, L. 1991a. A check-list of the diatoms in the Holocene deposits of the western Belgian coastal plain with a survey of their apparent ecological requirements. I. Introduction, ecological code and complete list. Belgische Geolgische Dienst. Professional Paper, 246: 1-41.

Denys, L. 1991b. A check-list of the diatoms in the Holocene deposits of the western Belgian coastal plain with a survcy of their apparent ecological requirements. II. Centrales. Belgische Geolgische Dienst. Professional Paper, 247: 1-92.

Falkowski, P. G., Biscaye, P. E. \& Sancetta, C. 1994. The lateral flux of biogenic particles from the eastern North American continental margin to the North Atlantic Ocean. Deep-Sea Research, 41: 583-601.

Garcia-Soto, C. \& Pingree, R. D. 1998. Late Autumn distribution and seasonality of chlorophyll-a at the shelf-break/slope region of the Armorican and Celtic shelf. Journal of the Marine Biological Association of the $U . K$, 78: 17-33.

Gardner, W. D. 1989. Baltimore Canyon as a modern conduit of sediment to the deep sea. Deep-Sea Research, 36: 323-358.

Graf, G. 1992. Benthic-pelagic coupling: a benthic view. Oceanography and Marine Biology Annual Review, 30: 149-90.

Hasle, G. R. 1976. The biogeography of some marine planktonic diatoms. Deep-Sea Research, 23: 319-338.

Hasle, G. R. \& Syvertsen, E. E. 1996. Marine Diatoms. In Tomas, C. R. (Ed.), Idenifying Marine Diatoms and Dinoflagellates, pp. $1-385$. Academic Press, Inc., San Diego.

Hendey, N. I. 1964. An Introductory Account of the Smaller Algae of British Coastal Waters, Part 5: Bacillariophyceae (Diatoms) Fish. Invest. Series IV. HMSO, London, 317pp.

Hustedt, F. 1927-1966. Die Kieselalgen Deutschlands, Österreichs un der Schweiz. In Rabenhorst, L. (Ed.), Kryptogamen-Flora von, Deutschland, Osterreichs und der Schweiz, Band 7, Teil 1: 1-920 (1927-1930); Teil 2: 1-845 (1931-1959); Teil 3: 1-816 (1961-1966). Eduard Kummer, Leipzig.

Huthnance, J. H. 1995. Circulation, exchange and water masses at the ocean margin: the role of physical processes at the shelf edge. Progress in Oceanography, 35: 353-431.

Kaland, P. E. \& Stabell, B. 1981. Methods for absolute diatom frequency analysis and combined diatom and pollen analysis in sediments. Nordic Joumal of Botany, 1: 697-700.

Koç Karpuz, N. \& Schrader, H. 1990. Surface sediment diatom distribution and Holocene paleotemperature variations in the Green- 
land, Iceland and Norwegian Sca. Paleoceanography, 5: 557-580.

Masson, D. G., Montadert, L. \& Scrutton, R. A. 1985. Regional geology of the Goban Spur continental margin. In De Graciansky, P. C. (Ed.), Initial Reports of the Deep-Sea Drilling Project, Leg 548 to 552, 1115 1139. US Government Printing Office, Washington, D. C.

Maynard, N. G. 1976. Relationship between diatoms in surface sediments of the Atlantic Ocean and the biological and physical oceanography of overlying waters. Paleobiology, 2: 99-121.

McCave, I. N., Hall, I. R., Antia, A. N. et al. 2000. Sources, distribution, composition and flux of suspended particulate material on the European margin $47-50^{\circ} \mathrm{N}$ : a synthesis of results from the OMEX I programme. Deep-Sea Research II (in press).

Pingree, R. D. \& Mardell, G. T. 1981. Slope turbulence, internal waves and phytoplankton growth at the Celtic Sea shelf break. Philosophical Transactions of the Royal Society of London, A302: 663-682.

Pingree, R. D., Holligan, P. M., Mardell, G. T. \& Head, R. N. 1976. The influence of physical stability on spring, summer and autumn phytoplankton blooms in the Celtic Sea. Journal of the Marine Biological Association of the United Kingdom, 56: 845-873.

Pokras, E. M. 1986. Preservation of fossil diatoms in Atlantic sediment cores: control by supply rate. Deep-Sea Research, 33: 893-902.

Rees, A., Joint, I. \& Donald, K. M. 1999. Early spring bloom phytoplankton-nutrient dynamics at the Celtic Sea Shelf Break. Deep-Sea Research, 46: 483-510

Ricard, M. 1987. Atlas du Phytoplankton Marin. 2 Editions du Centre National de la Recherche Scientifique, Paris, 297pp.

Rines, J. E. B. \& Hargraves, P. E. 1988. The Chaetoceros Ehrenberg (Bacillariophyceae) Flora of Narragansett Bay, Rhode Island, U.S. A. J. Cramer, Berlin, 196pp.

Ruddiman, W. F. \& McIntyre, A. 1976. Northeast Atlantic paleoclimatic changes over the past 600,000 years. Memoirs of the Geological Socicty of America, 145: 111-146.

Samtleben, C. \& Bickert, T. 1990. Coccoliths in sediment traps from the Norwegian Sea. Marine Micropaleontology, 16: 39-64.

Samtleben, C., Schäfer, P., Andruleit, H. et al. 1995. Plankton in the Norwegian-Greenland Sea: from living communities to sediment assemblages - an actualistic approach. Geologische Rundschau, 84: $108-136$.
Sancetta, C. 1982. Distribution of diatom species in surface sediments of the Bering and Okhotsk seas. Micropaleontology, 28: 221-257.

Sancetta, C. 1989. Processes controlling the accumulation of diatoms in sediments: a model derived from British Columbian fjords. Paleoceanography, 4: 235-251.

Sancetta, C. 1992. Comparison of phytoplankton in sediment trap series and surface sediments along a productivity gradient. Paleoceanography, 7: 183-194.

Sancetta, C. \& Calvert, S. E. 1988. The annual cycle of sedimentation in Saanich Inlet, British Columbia: implications for the interpretation of diatom fossil assemblages. Deep-Sea Research, 35: 71-90.

Schrader, H. J. 1973. Proposal for a standardized method of cleaning diatom-bearing deep-sea and land-exposed marine sediments. Nova Hedwigia, Beihefte, 45: 403-409.

Schrader, H. J. \& Gersonde, R. 1978. Diatoms and silicoflagellates. Utrecht Micropaleontological Bulletins, 17: 129-176.

Schrader, H., Swanberg, I. L., Burckle, L. H. \& Grønlien, L. 1993. Diatoms in recent Atlantic $\left(20^{\circ} \mathrm{S}\right.$ to $70^{\circ} \mathrm{N}$ latitude) sediments: abundance patterns and what they mean. Hydrobiologia, 269/270: $129-135$.

Thomsen, L. \& van Weering, Tj. C. E. 1998. Spatial and temporal variability of particulate matter in the benthic boundary layer at the N. W. European Continental Margin (Goban Spur). Progress in Oceanography, 42: 61-76.

van Weering, Tj. C. E., Hall, I. R., de Stigter, H. C., McCave, I. N. \& Thomsen, L. 1998. Recent sediments, sediment accumulation and carbon burial at Goban Spur, N. W. European Continental Margin $\left(47^{\circ}-50^{\circ} \mathrm{N}\right)$. Progress in Oceanography, 42: 5-35.

Walsh, J. J. 1991. Importance of continental margins in the marine biogeochemical cycling of carbon and nitrogen. Nature, 350: 53-55.

Walsh, J. J., Rowe, G. T., Iverson, R. L. \& McRoy, C. P. 1981 Biological export of shelf carbon: a neglected sink of the global $\mathrm{CO}_{2}$ cycle. Nature, 291: 196-201.

Weston, J. F. 1985. Comparison between recent benthic foraminiferal faunas of the Porcupine Seabight and Western Approaches Continental Slope. Journal of Micropalaeontology, 4: 165-183. 